\title{
Influence of Annealing Treatments on Welded CuNi Sheets on the Corrosion Behaviour in Sea Water
}

\author{
Maria Victoria Biezma', Paul Linhardt², Susanne Strobl'², and Roland Haubner ${ }^{2}$ \\ 'University of Cantabria, Santander, Spain \\ ${ }^{2}$ Technische Universität Wien, Vienna, Austria
}

Received April 30, 2021; accepted June 25, 2021; published online July 20, 2021

\begin{abstract}
Due to their good corrosion resistance in seawater, tubes, rods, and forgings made from copper-nickel alloys (Cu-Ni) are widely used in ship building, offshore platforms, desalination plants, and numerous other applications. Welding is a major technology for joining this material. Since the microstructures of base material, weld seam, and heat affected zone may be quite different, the consequences with respect to corrosion must be considered. In this study the influence of microstructure on corrosion behaviour was investigated using welded test coupons of $\mathrm{CuNi} 10 \mathrm{Fe} 1.6 \mathrm{Mn}$, as-welded and after heat-treatment, by metallographic examination and electrochemical corrosion tests in synthetic seawater.
\end{abstract}

Keywords: Copper-nickel alloy, Weld, Corrosion tests, Synthetic seawater

Einfluss von Wärmebehandlungen an geschweißten CuNi Blechen auf das Korrosionsverhalten in Meerwasser

Zusammenfassung: Aufgrund ihrer guten Korrosionsbeständigkeit in Meerwasser werden Rohre, Stangen, Schmiedestücke aus Kupfer-Nickel-Legierungen (Cu-Ni) im Schiffsbau, auf Erdöl-Bohrplattformen, in Meerwasserentsalzungsanlagen und zahlreichen anderen Anwendungen eingesetzt. Dabei ist Schweißen eine wesentliche Technologie zum Fügen. Da sich die Gefüge von Grundwerkstoff, Schweißnaht und Wärmeeinflusszone stark unterscheiden können, muss die Auswirkung auf Korrosion berücksichtigt werden. In diesem Beitrag wurden der Einfluss des Gefüges auf das Korrosionsverhalten von geschweißten Probestücken aus CuNi10Fe1.6Mn im Ausgangszustand und nach Wärmebehandlung durch Metallographie und elektrochemische Korrosionsprüfungen in künstlichem Meerwasser untersucht.

Prof. Dr. P. Linhardt $(\bowtie)$

Technische Universität Wien,

Getreidemarkt 9/164-03,

1060 Vienna, Austria

paul.linhardt@tuwien.ac.at
Schlüsselwörter: Kupfer-Nickel-Legierung, Schweißnaht, Korrosionstest, Künstliches Meerwasser

\section{Introduction}

Copper-nickel alloys (Cu-Ni) have been in extensive use in seawater applications for many years. These materials offer a good corrosion resistance and excellent antifouling properties [1]. The addition of nickel to copper improves the resistance against uniform and pitting corrosion and increases the mechanical strength of the alloys [2-5]. The higher corrosion resistance of $\mathrm{Cu}-\mathrm{Ni}$ alloys is attributed to the fact that nickel ions are incorporated in the $\mathrm{Cu}_{2} \mathrm{O}$ barrier layer formed, which leads to a reduced ionic conductivity in the $\mathrm{Cu}_{2} \mathrm{O}$ and thus to a higher corrosion resistance [6]. In the presence of $\mathrm{CO}_{2}$ in the medium, other reactions and formation of carbonates take place [7].

It has been shown that, with increasing $\mathrm{Ni}$ content up to $30 \%$, the resistance of $\mathrm{Cu}-\mathrm{Ni}$ in acidic chloride solutions increases. However, with an even higher Ni content, a reduction in the corrosion resistance of $\mathrm{Cu}-\mathrm{Ni}$ alloys is observed [8]. In alkaline solutions containing chloride, nickel contents above $10 \%$ deteriorate the pitting corrosion resistance [2]. In general, the corrosion resistance of copper nickel alloys decreases with chloride concentration and temperature $[3,6,9-11]$. The addition of some iron to $\mathrm{Cu}-\mathrm{Ni}$ alloys was found to further improve the corrosion resistance against seawater [12].

The aim of this contribution is to investigate the corrosion behaviour of iron containing alloy type 90/10 $\mathrm{Cu}-\mathrm{Ni}$ sheets welded with 80/20 Cu-Ni filler metal in synthetic sea water. Manufactured as tubes, this material is extensively applied as cooling water pipes for ship engines, transporting sea water from the intake to the coolers where the heat exchange to the fresh water filled secondary cooling circuit takes place. The temperature and pressure of these lines range from 11 to $20^{\circ} \mathrm{C}$ and from 7 to 11 bar, respectively. In order to estimate the influence of the heat-affected zone, 


\begin{tabular}{lllllllllll}
\hline \multicolumn{1}{|l}{ TABLE 1 } \\
Chemical composition (wt. \%) of the CuNi10Fe1.6 Mn sheets (batch analysis from the producer)
\end{tabular}

some samples were also subjected to various heat treatments.

\section{Experimental}

\subsection{Specimen Preparation}

Welded sheets of CuNi10Fe1.6 Mn (according to DIN WL 2.1972) with a thickness of $3 \mathrm{~mm}$ were achieved by cutting from a tube of $152 \mathrm{~mm}$ diameter carrying a circumferential weld. The weld filler was CuNi20 (Mat. No. 2.0822 according to DIN 17664), and a two-pass TIG (tungsten inert gas) process under argon $(5-10 \mathrm{~L} / \mathrm{min})$ was applied. The alloy composition of the parent material (sheet) according to the batch analysis from the producer is provided in Table 1.

These as-received samples were 70 by $40 \mathrm{~mm}^{2}$ in size with the $40 \mathrm{~mm}$ long weld seam in the middle. Some samples were subjected to heat treatments in a tube furnace in an argon atmosphere to prevent oxidation. A first annealing occurred at $700^{\circ} \mathrm{C}$ for $4 \mathrm{~h}$, followed by water quenching. Some of these samples were annealed in a subsequent step at $200^{\circ} \mathrm{C}$ for 12,50 , or $100 \mathrm{~h}$, respectively.

As-received and heat treated samples were cut perpendicular to the weld seam into $3 \mathrm{~mm}$ wide and $25 \mathrm{~mm}$ long slices with the weld in the middle position. These specimens were used for metallographic investigation of the cross section and for electrochemical corrosion tests.

\subsection{Metallographic Investigation}

The sectioned specimens were warm mounted in phenolic resin. The metallographic preparation was with 320 grit SiC paper for plane grinding, followed by fine grinding and polishing with 9, 3, $1 \mu \mathrm{m}$ diamond suspensions and finally with a $0.05 \mu \mathrm{m}$ alumina suspension. To reveal the microstructure, a cupric ammonium chloride $\left(\mathrm{NH}_{4}\right)_{2} \mathrm{CuCl}_{4} \cdot 2 \mathrm{H}_{2} \mathrm{O}$-solution was used [13].

Metallographic investigations were performed using a light optical microscope (LOM) and a FEI QUANTA $200 \mathrm{~K}$ scanning electron microscope (SEM), equipped with energy dispersive $\mathrm{X}$-ray analysis (EDX). SEM-images were acquired in back scattered electron (BSE) mode.

\subsection{Electrochemical Corrosion Testing}

The sectioned specimens were ground with a 600 grit SiC paper for electrochemical corrosion testing. The electrolyte was synthetic sea water (SSW) according to DIN 50905-4, which was prepared by dissolving the respective amounts of $\mathrm{NaCl}, \mathrm{NaHCO}_{3}, \mathrm{Na}_{2} \mathrm{SO}_{4}, \mathrm{MgCl}_{2} \cdot 6 \mathrm{H}_{2} \mathrm{O}$, and $\mathrm{CaCl}_{2} \cdot 2 \mathrm{H}_{2} \mathrm{O}$ in deionized water.
The tests were carried out under potentiostatic control in a cylindrical container (approx. $30 \mathrm{~cm}$ in diameter) filled with $6 \mathrm{I}$ of SSW. A cylinder made from a stainless steel mesh was placed inside along the container wall, serving as a counter electrode. A silver/silver chloride electrode (SSE, $0 \mathrm{mV}_{\mathrm{SSE}}=+198 \mathrm{mV}$ vs. the standard hydrogen electrode, SHE) served as a reference electrode and was inserted from top in the centre of the container.

For each test, four specimens acting as working electrodes were electrically contacted by clamping to suitably bent stainless steel wires and placed symmetrically around the reference electrode inside the container. It should be noted that the contacting wires remained passive throughout the tests and the crevice effect at the points of contact was kept negligible by minimizing the area of contact.

The four specimens were polarized to $-150,-100,-50$, and $0 \mathrm{mV}_{\mathrm{SSE}}$, respectively, controlled by a multichannel potentiostat (Octopoti, home-made [14]) hooked to a data acquisition system for logging the individual currents throughout the test duration of $70 \mathrm{~h}$. The total currents of the specimens (all very close to $3.2 \mathrm{~cm}^{2}$ surface area) are presented here, since calculating the current density may be misleading due to the heterogeneous character of the surface (weld/heat affected zone/base metal).

After the tests, the morphology of surface attack and the corrosion products were assessed by a 3D-digital microscope (3D-DM, Keyence) and SEM in BSE mode.

\section{Results and Discussion}

\subsection{Characterization of the As-received Material}

An overview of the two-layered weld seam joining two sheets of parent material is presented as cross section in Fig. 1a.

A banded structure characteristic for rolled material can be seen in the parent material, which may be traced back to local differences in the $\mathrm{Cu}$ :Ni ratios [12] revealed by the etching (Fig. 1b, c).

In the area of the weld seam, dendritic solidification structures are visible (Fig. 1d, e). SEM-EDX analysis data from the sheet metal (on the left in Fig. 1f) and weld (on the right in Fig. 1f) are provided in Table 2 for comparison. These data confirm that the filler material with approx. $20 \mathrm{wt}$. \% Ni has a significantly higher Ni content than the sheet material.

The transition between sheet metal and weld seam is very fine-grained, and the grain boundaries in the heat-affected zone next to the weld are more strongly attacked by etching than in the parent sheet metal (Fig. 1g, h). The latter may be attributed to elevated $\mathrm{Ni}$ concentration in the grain boundaries, introduced during welding by the diffusion from the filler metal more rich in $\mathrm{Ni}$. 


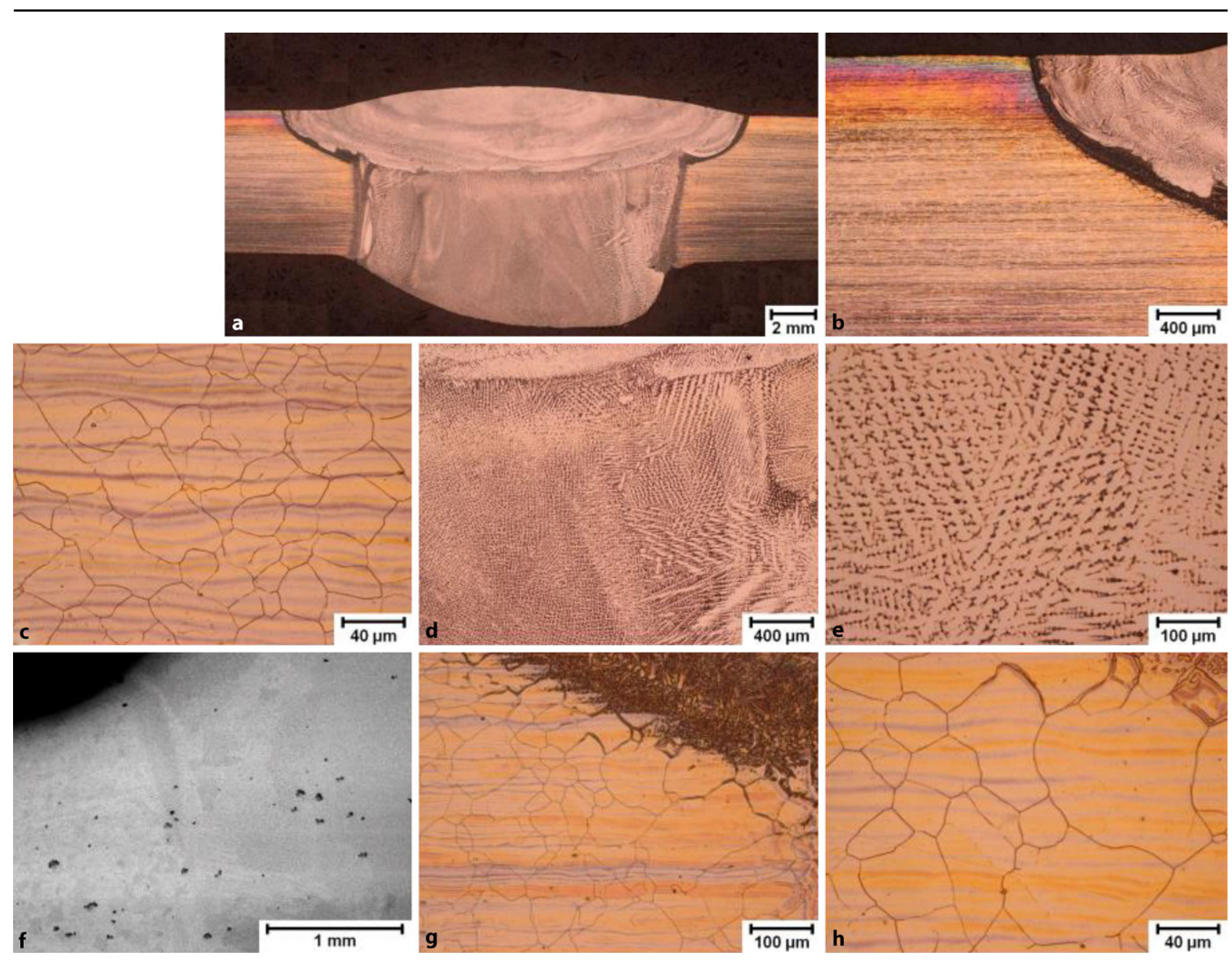

Fig. 1: As-received welded sheets, a overview, $\mathbf{b}, \mathbf{f}$ transition from parent metal to weld seam, $\mathbf{c}$ parent metal, $\mathbf{d}, \mathbf{e}$ weld, $\mathbf{g}, \mathbf{h}$ heat affected zone (etchant: $\left(\mathrm{NH}_{4}\right)_{2} \mathrm{CuCl}_{4} .2 \mathrm{H}_{2} \mathrm{O}$-solution). a-e, g, h LOM. f SEM

\subsection{Microstructural Changes During the Heat Treatments}

For comparison, the views of the microstructures of all samples are compiled in Fig. 2. After heat treatment for $4 \mathrm{~h}$ at $700^{\circ} \mathrm{C}$, the banded structure appears much weaker compared to the as-received sample, but the shape and size of the equiaxed grains did not change.

Subsequent annealing at $200^{\circ} \mathrm{C}$ leads again to a banded and well defined microstructure after 12 and $50 \mathrm{~h}$, while, with an increasing annealing time, the visibility of the grain boundaries fades away in comparison to the as-received sample. The bands appear more continuous after $50 \mathrm{~h}$, but after $100 \mathrm{~h}$ they have almost disappeared again and equiaxial grains dominate the microstructure. It is unclear

\begin{tabular}{|c|c|c|c|c|}
\hline \multicolumn{5}{|c|}{$\begin{array}{l}\text { TABLE } 2 \\
\text { SEM-EDX analysis data (wt. \%) from a metallograph- } \\
\text { ically prepared as-received sample (Fig. 1f) }\end{array}$} \\
\hline & $\mathrm{Cu}$ & $\mathrm{Ni}$ & $\mathrm{Mn}$ & $\mathrm{Fe}$ \\
\hline Sheet & 86.6 & 10.2 & 1.1 & 2.0 \\
\hline Weld & 75.8 & 21.5 & 1.5 & 1.3 \\
\hline
\end{tabular}

whether this effect is related to the solution heat treatment and a subsequent formation of kappa-micro-precipitates as observed and reported by Drolenga et al. [12]. In general, annealing results in a slight coarsening of the grain size in the parent metal.

At the weld seam, the microstructure observed in the as-received material disappears partially after annealing at $700^{\circ} \mathrm{C}$ for $4 \mathrm{~h}$, and epitaxial growth along inter-dendritic bands occurred as consequence of the variations in the thermal gradient during quenching. After further annealing at $200^{\circ} \mathrm{C}$ for 12 and $50 \mathrm{~h}$, zones free of dendrites and areas with shorter dendrite arms appear, while after $100 \mathrm{~h}$, an almost full recovery of a homogeneous, equiaxed, and branched dendritic microstructure is observed.

\subsection{Electrochemical Corrosion Tests}

The recorded current-time traces of the specimens from the as-received material tested potentiostatically in SSW at the selected potentials are presented in Fig. 3 in linear and logarithmic scaling. The shape and basic features of these 


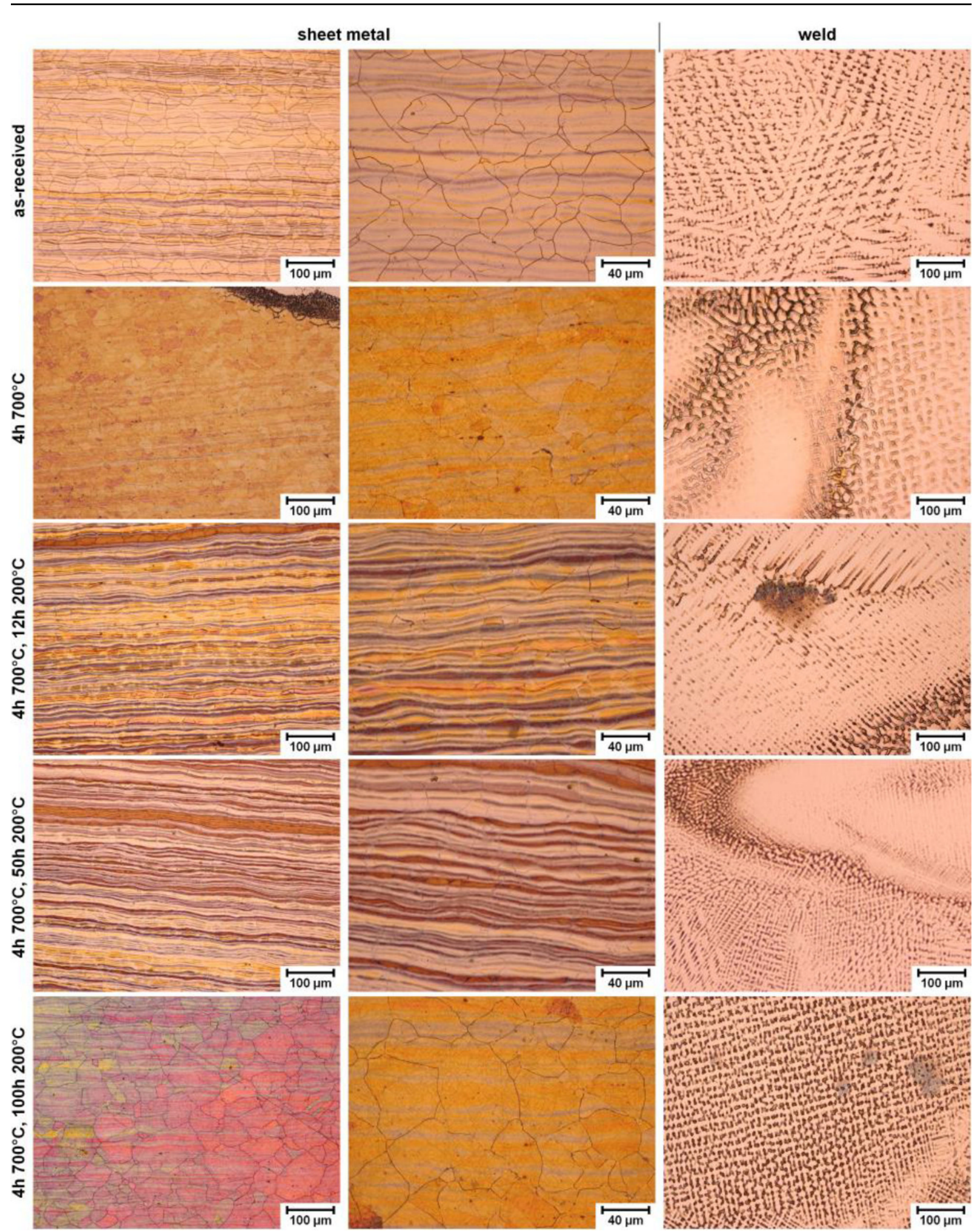

Fig. 2: Microstructures of parent metal and weld of the as-received and the heat treated samples. (etchant: $\left(\mathrm{NH}_{4}\right)_{2} \mathrm{CuCl}_{4} \cdot 2 \mathrm{H}_{2} \mathrm{O}$-solution) 

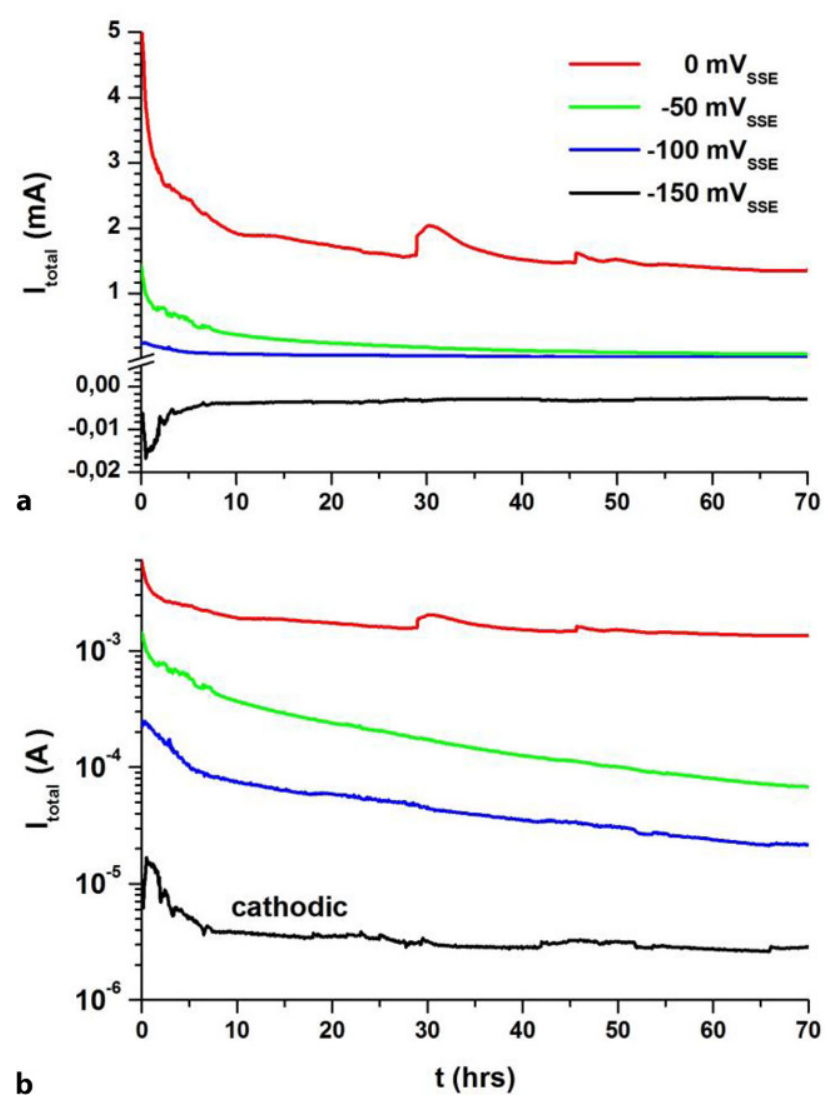

Fig. 3: Currents recorded during potentiostatic corrosion testing of the as-received sample in SSW, in linear (a) and logarithmic (b) scaling

curves are also representative for the data received from the heat treated samples.

For the test potential of $-150 \mathrm{mV}_{\mathrm{SSE}}$, low cathodic currents from reduction of the oxygen dissolved in and diffusing into the electrolyte were established, while, at $-100 \mathrm{mV}_{\mathrm{SSE}}$, an anodic current of metal dissolution was observed. We may conclude that the free corrosion potential must be between these two test potentials.

For the most anodic test potential, i.e. $0 \mathrm{mV}_{\mathrm{SSE}}$, a rather high current of almost $6 \mathrm{~mA}$ is established by the blank metal at first contact with the electrolyte. Due to formation of a more or less protective layer of corrosion products, the current drops rapidly and levels off at approximately $2 \mathrm{~mA}$ after $10 \mathrm{~h}$, being quite constant for the rest of the experiment, i.e. up to $70 \mathrm{~h}$. Spontaneous current peaks, here visible after 30 and $45 \mathrm{~h}$, are related to the flaking off of parts of this porous and mechanically unstable layer.

Just $50 \mathrm{mV}$ below the most positive testing potential,

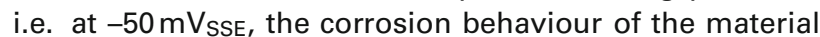
is quite different. Although the initial current of more than $1 \mathrm{~mA}$ appears relatively high, it drops rapidly within the first few hours and continues with a still declining trend after $70 \mathrm{~h}$, being approximately 1 order of magnitude lower than the current observed at $0 \mathrm{mV}_{\text {SSE }}$ at that time. These observations are related to the relatively passive behaviour of copper alloys in seawater up to a critical potential, above which high corrosion rates are found. In this case, we may con-
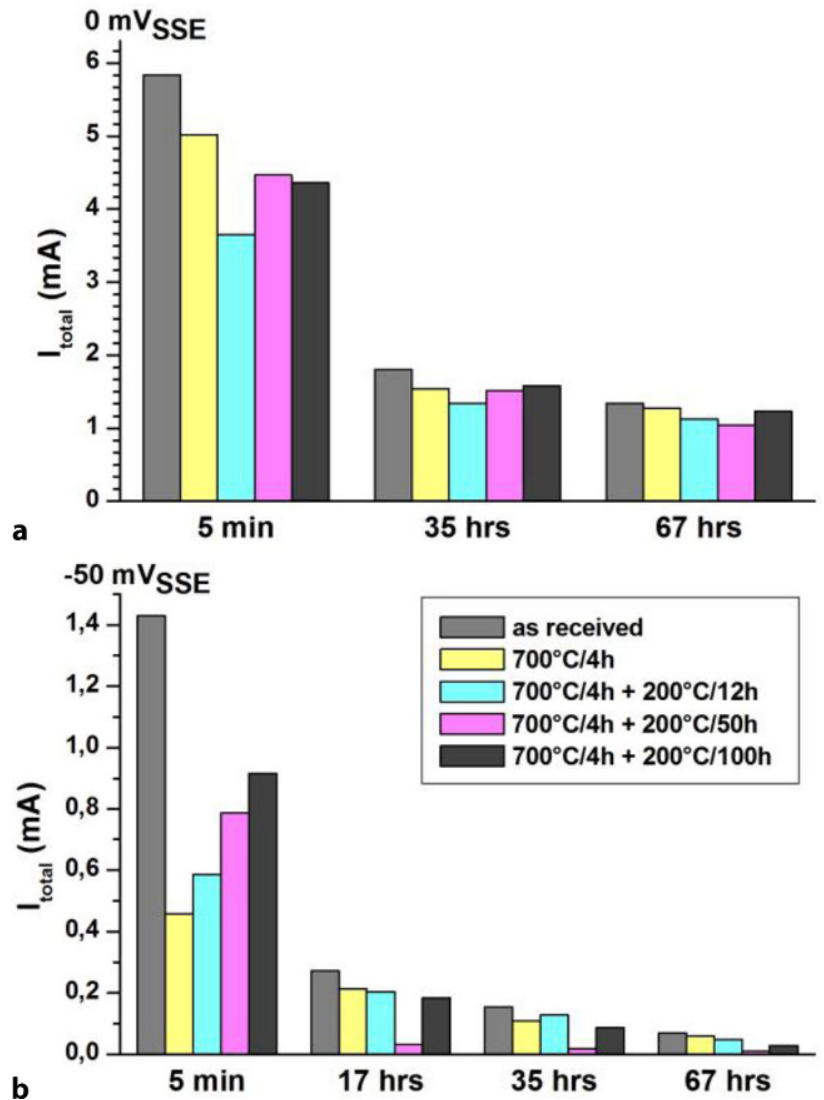

Fig. 4: Anodic currents observed at different times of potentiostatic corrosion tests in SSW at 0 (a) and -50 (b) $\mathrm{mV}$ SSE for the as-received and heat treated samples

clude that this critical potential falls in the potential range between -50 and $0 \mathrm{mV} V_{\text {SSE }}$.

For a comparison of the data from all the samples, the currents observed at selected times $(5 \mathrm{~min}, 35$ and $67 \mathrm{~h}$, respectively) have been compiled in Fig. 4 for the two most anodic test potentials. At $0 \mathrm{mV}_{\mathrm{SSE}}$, the as-received and the heat treated samples exhibit a very similar behaviour. The drop of the initial current leads to very similar values for all samples after $35 \mathrm{~h}$ and after $67 \mathrm{~h}$. All the currents are still high and fall in the narrow span of 1.0-1.3 mA, with the maximum value from the as-received and the minimum from the sample annealed at $200^{\circ} \mathrm{C}$ for $50 \mathrm{~h}$, respectively.

At the test potential of $-50 \mathrm{mV} V_{S S E}$, the decay of currents from the high initial values appears much faster. After $17 \mathrm{~h}$, the sample annealed at $200^{\circ} \mathrm{C}$ for $50 \mathrm{~h}$ established a significantly lower anodic current compared to the other samples. This trend continues steadily with time, and, after $67 \mathrm{~h}$, the lowest anodic current is observed for the sample treated at $200^{\circ} \mathrm{C} / 50 \mathrm{~h}(+10 \mu \mathrm{A})$, while the highest current $(+70 \mu \mathrm{A})$ is delivered by the as-received sample.

\subsection{Characterization of the Corroded Surfaces}

After the corrosion tests, an examination by means of 3DDM was carried out and views of all samples are compiled for a comparison for selected test potentials in Fig. 5. For 


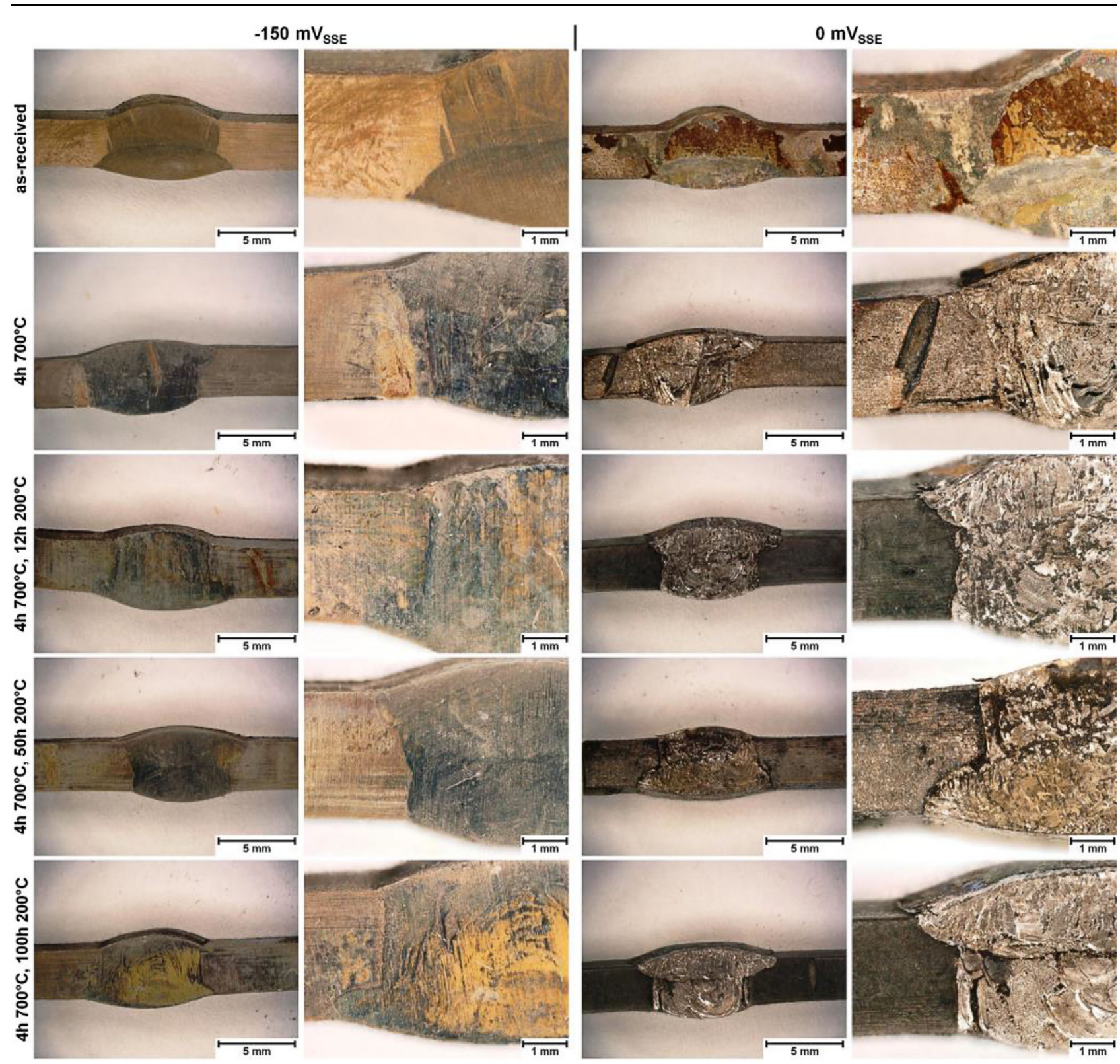

Fig. 5: Surface inspection by 3D-DM: Specimens after the corrosion tests in SSW for $70 \mathrm{~h}$ at -150 and $0 \mathrm{mVSSE}$

the lowest potential ( $\left.-150 \mathrm{mV}_{\mathrm{SSE}}\right)$, due to the cathodic state, no material loss is visually observed, but a brown discoloration occurred at the sheet and weld with a varying intensity, strongly depending on the heat treatment.

For the specimens polarized to the most anodic potential $\left(0 \mathrm{mV}_{\mathrm{SSE}}\right)$, however, an intense corrosion attack has been observed. On the as-received specimen, left patches of brown corrosion products indicate that just loosely adhering layers have formed during the test. In the SEM-BSE view (Fig. 6), the surfaces of the weld seam and sheet metal appear very similar, i.e. no selectivity in the attack is observed.

On the sample annealed for $4 \mathrm{~h}$ at $700^{\circ} \mathrm{C}$, the brown colorations are similar, but bright areas appear in the weld seam. In SEM-BSE view, the surface of the sheet appears darker than the weld seam, indicating a rather uniform layer of corrosion products on the sheet, while the weld seam is rather blank. Spots of corrosion products appear in the transition zone from parent metal to weld seam.

The dendrites in the weld seam, which are rich in copper and form first during the solidification process, appear more severely attacked than the nickel-rich inter-dendritic areas.

The different annealing times at $200^{\circ} \mathrm{C}$ result in a similar picture, with the sheet metal surface appearing evenly dark brown and bright areas appearing in the weld seam. With an increasing annealing time, the effects of the dendrites and the inter-dendritic phase decrease in the weld seam. This may be explained by the diffusion-driven equalization of concentration gradients. 


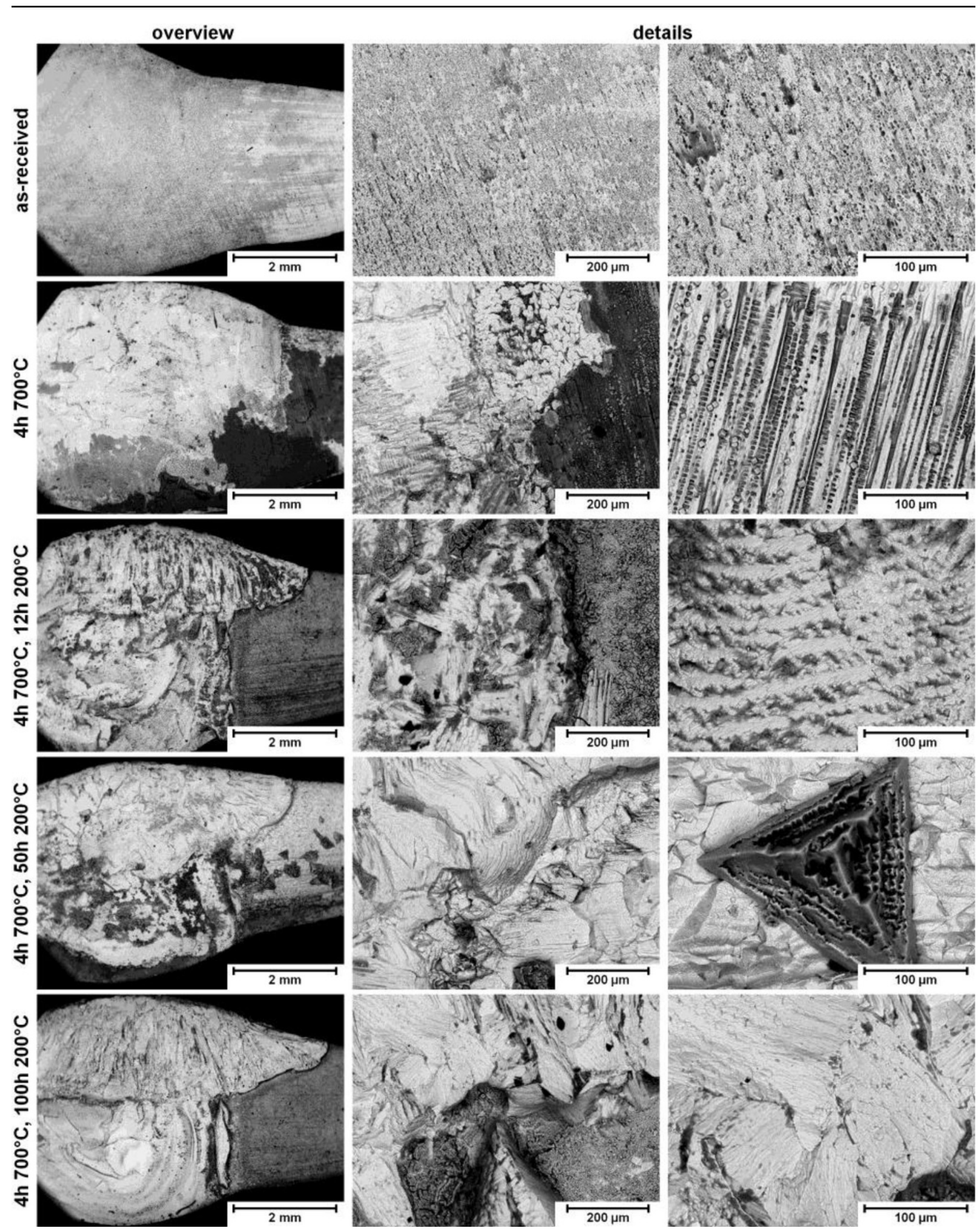

Fig. 6: Observation by SEM in BSE mode: Surfaces of the specimens after the corrosion test at $0 \mathrm{mVSSE}$ in SSW for $70 \mathrm{~h}$ 


\section{Discussion}

The investigated joint of parent material (CuNi10Fe1.6 Mn) and weld filler made from a different alloy $(\mathrm{CuNi20})$ is an inhomogeneous material, and consequences for the corrosion behaviour are to be expected. Moreover, the twopass-weld itself is of an inhomogeneous structure due to the precipitation effects during solidification. Copper rich dendrites are formed first and the inter-dendritic alloy is enriched in nickel. During the corrosion in synthetic seawater, the copper rich dendrites extending to the surface of the weld seam corrode preferentially. However, after the dissolution of these surface-near dendrites, since they are surrounded by the nickel-rich inter-dendritic phase, the corrosion at the weld seam will cease and the further corrosion process will be dominated by a dissolution of the parent metal. The heat affected zone was found rather narrow and did not exhibit any particularly different corrosion behaviour.

The free corrosion potential of the investigated samples was found to be in the interval -150 to $-100 \mathrm{mV}_{\text {SSE }}$ and, at some critical potential, between -50 and $0 \mathrm{mV}$ SSE, a significant transition in the corrosion behaviour occurs. At potentials below this critical value, passivation takes place, however slowly, and this process is not yet completed even after 3 days. This is typical for copper alloys with their sluggish reaction kinetics, and which is more conveniently assessed by potentiostatic rather than by potentiodynamic experiments. By contrast, at potentials more positive than the critical value, a rather active corrosion takes place and a kind of steady state corrosion rate is established within a couple of hours by the formation of a moderately protective layer of corrosion products. From a practical point of view, this transition in corrosion behaviour must be taken into account when galvanic couples with metals with high free corrosion potentials, like stainless steel or titanium, are considered in a system.

The heat treatments performed in this study mainly equilibrated concentration gradients in alloying elements in the weld seam by diffusion. In comparison to the as-received material, annealing at $700^{\circ} \mathrm{C}$ for $4 \mathrm{~h}$ followed by $50 \mathrm{~h}$ at $200^{\circ} \mathrm{C}$ improved the passivation process at the test potential of $-50 \mathrm{mV}$ SSE remarkably in terms of kinetics and passive current, while the effect on the trans-passive behaviour assessed at $0 \mathrm{mV}_{\text {SSE }}$ was not significant. The improved behaviour in the passive range seems to correlate with the appearance of the banded microstructure in combination with the disappearance of the micro-precipitates in the grain boundaries of the sheet metal. Annealing at $700^{\circ} \mathrm{C}$ for $4 \mathrm{~h}$ followed by $100 \mathrm{~h}$ at $200^{\circ} \mathrm{C}$ did not improve the corrosion behaviour significantly compared to the asreceived sample, which coincides with the disappearance of the banded structure and reappearance of the marked grain boundaries.

\section{Conclusions}

The investigated welded joint made of a sheet of alloy CuNi10Fe1.6 Mn and a weld filler corresponding to CuNi20 is an inhomogeneous material, macroscopically by the different nature of the parent metal and weld seam and microscopically due to precipitation effects during solidification of the weld.

Potentiostatic corrosion tests in synthetic seawater with as-welded and post-welding heat treated samples indicated a passive range ca. $100 \mathrm{mV}$ wide for all samples. Even after 3 days, the passivation process continues with the passive current still dropping. Among the various heat treatments, annealing at $700^{\circ} \mathrm{C}$ for $4 \mathrm{~h}$, quenching and further annealing at $200^{\circ} \mathrm{C}$ for $50 \mathrm{~h}$ resulted in the lowest passive current, while extending the second annealing to $100 \mathrm{~h}$ reestablished the corrosion behaviour of the as-received material. Basically, the applied heat treatments equilibrated the concentration gradients in the alloying elements and possibly had some effect on the micro-precipitates.

At the applied test potential in the transpassive range, no significant influence of the heat treatments on the corrosion behaviour was found. In the beginning, corrosion attacks preferentially the surface-near copper rich dendrites in the weld. However, this process ceases due to the Ni-rich interdendritic phase being more corrosion resistant. Further corrosion then is dominated by the uniform dissolution of the parent metal, controlled by a moderately protecting layer of corrosion products. No particular corrosion effect was observed at the narrow heat affected zone.

It may be concluded that a well-controlled thermal treatment of welded CuNi10Fe1.6 Mn may potentially improve the corrosion behaviour in the passive operating range of the alloy in seawater.

Acknowledgements. We would like to thank Mr Osman Alacamlioglu for his help with the experimental implementation during his work on his bachelor's thesis, and Dr Porras and Mr Colvé of Astilleros de Santander, S.A.U. (Astander), Spain, for providing the welded specimens.

Funding. Open access funding provided by TU Wien (TUW).

Open Access This article is licensed under a Creative Commons Attribution 4.0 International License, which permits use, sharing, adaptation, distribution and reproduction in any medium or format, as long as you give appropriate credit to the original author(s) and the source, provide a link to the Creative Commons licence, and indicate if changes were made. The images or other third party material in this article are included in the article's Creative Commons licence, unless indicated otherwise in a credit line to the material. If material is not included in the article's Creative Commons licence and your intended use is not permitted by statutory regulation or exceeds the permitted use, you will need to obtain permission directly from the copyright holder. To view a copy of this licence, visit http://creativecommons.org/licenses/by/4.0/.

\section{References}

1. Powell C. A.; Michels H. T.: Copper-nickel alloys for seawater corrosion resistance and Antifouling-A state of the art review, Corrosion 2000, NACE, March 2000

2. Milošev, I.; Metikoš-Huković, M.: The behavior of $\mathrm{Cu}-\mathrm{xNi}$ ( $\mathrm{x}=10$ to $40 \%$ ) alloys in alkaline solutions containing chloride ions, Electrochimica Acta, 42 (1997), pp 1537-1548

3. Badawy, W. A.; Ismail, K. M.; Fathi, A. M.: The influence of copper/ nickel ratio on the electrochemical behavior of $\mathrm{Cu}-\mathrm{Ni}$ alloys in acidic sulfate solutions, Journal of Alloys and Compounds, 484 (2009), pp 365-370 
4. Badawy, W. A.; Ismail, K. M.; Fathi, A. M.: Effect of Ni on the corrosion behavior of $\mathrm{Cu}-\mathrm{Ni}$ alloys in neutral chloride solutions, Electrochimica Acta, 50 (2005), pp 3603-3608

5. North, R. F; Pryor, M. J.: The Influence of corrosion product structure on the corrosion rate of $\mathrm{Cu}-\mathrm{Ni}$ alloys, Corrosion Science, 10 (1970), pp 297-311

6. Wang, Y. Z.; Beccaria, A. M.; Poggi, G.: The effect of temperature on the corrosion behavior of 70/30 Cu-Ni commercial alloy in seawater, Corrosion Science, 36 (1994) pp 1277-1288

7. Ezuber, H. M.; Al-Shater, A.; Murra, F; Al-Shamri, N.: Corrosion Behavior of Copper-Nickel Alloys in Seawater Environment, $16^{\text {th }}$ Middle East Corrosion Conference and Exhibition, 2016, Kingdom of Bahrain, NACE Paper No. MECCFEB16-8103, 2016

8. Ismail, K.; Fathi, A.; Badawi, W.: Electrochemical behavior of copper alloys in acidic chloride solutions, Corrosion Science, 48 (2006), pp 1912-1925

9. Ezuber, H.: Effect of temperature and thiosulfate on the corrosion behavior of 90-10 coppernickel alloys in seawater, Anti-Corrosion Methods and Materials, 56 (2009), pp 168-172
10. Ezuber, H. M: Role of iron content on the corrosion behavior of 90-10 $\mathrm{Cu}-\mathrm{Ni}$ alloys in $3.5 \% \mathrm{NaCl}$, Anti-Corrosion methods and Materials, 59 (2012), pp 195-202

11. Ezuber, H.; Al-Shater A.: Influence of environmental parameters on the corrosion behavior of $90 / 10$ cupronickel tubes in $3.5 \% \mathrm{NaCl}$, Desalination and Water Treatment, 26 (2015), pp. 1-11

12. Drolenga, L. J. P.; ljsseling, F. P.; Kolster, B. H.: The Influence of Alloy Composition and Microstructure on the Corrosion Behaviour of Cu-Ni Alloys in Seawater, Werkstoffe und Korrosion, 34 (1983), pp 167-178

13. Vander Voort, G. F: Metallography-Principles and Practice, 3rd ed., ASM International, Materials Park, $\mathrm{OH}, 2004$

14. Linhardt, P.; Kührer, S.; Ball, G.; Biezma, M. V.: Design of a Multichannel Potentiostat and Its Application to Corrosion Testing of Nickel Aluminium Bronze, Materials and Corrosion, 69 (2018), pp 358-364

Publisher's Note. Springer Nature remains neutral with regard to jurisdictional claims in published maps and institutional affiliations. 